ISSN 1392-3196 / e-ISSN 2335-8947

Zemdirbyste-Agriculture, vol. 104, No. 2 (2017), p. 185-190

DOI 10.13080/z-a.2017.104.024

\title{
Rootstock vigour and leaf colour affect apple tree nutrition
}

\author{
Darius KVIKLYS ${ }^{1}$, Juozas LANAUSKAS ${ }^{1}$, Nobertas USELIS ${ }^{1,3}$, Jonas VIŠKELIS ${ }^{1}$, \\ Alina VIŠKELIENE' 1 , Loreta BUSKIENE ${ }^{1}$, Gediminas STAUGAITIS ${ }^{2}$, \\ Romas MAŽEIKA ${ }^{2}$, Giedrè SAMUOLIENE ${ }^{1,3}$ \\ ${ }^{1}$ Institute of Horticulture, Lithuanian Research Centre for Agriculture and Forestry \\ Kauno 30, Babtai, Kaunas distr., Lithuania \\ E-mail: dkviklys@1sdi.lt \\ ${ }^{2}$ Agrochemical Research Laboratory, Lithuanian Research Centre for Agriculture and Forestry \\ Savanorių 287, Kaunas, Lithuania \\ ${ }^{3}$ Aleksandras Stulginskis University \\ Studentų 11, Akademija, Kaunas distr., Lithuania
}

\begin{abstract}
Nutrient uptake and transport depend on the root system of a tree. Various apple rootstock genotypes may interact fruit tree nutrition. The effect of apple (Malus $\times$ domestica Borkh.) rootstocks (M.9, M.26, B.396, P22, P59, P61, P62, P66, P67, Pure 1 and PB.4) on the mineral nutrition of leaf and fruit was studied in 2013-2015. The leaf and fruit mineral concentration for nitrogen $(\mathrm{N})$, phosphorus $(\mathrm{P})$, potassium $(\mathrm{K})$, calcium $(\mathrm{Ca})$, magnesium $(\mathrm{Mg})$, and leaf mineral content for copper $(\mathrm{Cu})$, zinc $(\mathrm{Zn})$, iron $(\mathrm{Fe})$, manganese $(\mathrm{Mn})$ and boron $(\mathrm{B})$ were measured. Apple trees on semi-dwarf M.26 and dwarf P67 rootstocks accumulated more minerals in leaves and fruits. The highest negative deviation from optimal nutrient content was detected in leaves from trees on super-dwarf rootstock P59. Red-leaved rootstocks accumulated significantly more $\mathrm{Ca}$ in leaves and fruits of scion cultivar and determined significantly lower $\mathrm{K}, \mathrm{N}$ and $\mathrm{Mg}$ ratios to $\mathrm{Ca}$. Rootstock vigour had impact only on leaf $\mathrm{Ca}$ and $\mathrm{Mg}$. More dwarfing rootstocks determined higher content of $\mathrm{Ca}$ and lower content of $\mathrm{Mg}$. More vigorous rootstocks had positive effect on fruit $\mathrm{K}$ and $\mathrm{P}$, while dwarfing on $\mathrm{K}, \mathrm{N}$ and $\mathrm{Mg}$ ratios to $\mathrm{Ca}$. Based on rootstock selectivity to accumulate certain minerals, by choosing the right rootstock genotype we can create orchards tolerant of unfavourable soil conditions.
\end{abstract}

Keywords: fruit, leaf, Malus $\times$ domestica, mineral content.

\section{Introduction}

A proper rootstock choice is the key factor for the establishment of modern apple orchard. During the centuries apple rootstocks have been selected for their tree vigour control, early and abundant bearing. Later studies paid attention to rootstock effect on fruit quality parameters such as size, weight, colour and biochemical content or fruit storability, rootstock effect on tree physiological processes (Wertheim, 1998; Samuolienè et al., 2016). Recent apple rootstock studies have been dedicated to enhanced apple tree resistance to various pest and diseases, adaptability to replant problems and different soil conditions (Auvil et al., 2011; Kviklys et al., 2016 a).

Rootstock plays a primary role in uptake and transport of water and minerals to scion variety. Nutrient absorption and translocation to different organs is a very important trait of a rootstock. Rootstocks may be selective in nutrient uptake, therefore by choosing the right rootstock genotype we can create orchards tolerant of unfavourable soil or growing environment conditions (Fazio et al., 2013).

Rootstock effect on the content of minerals in leaves is contradictory. Some studies have indicated insignificant effect of rootstock on leaf elemental composition (Joubert et al., 2011), whereas other studies pointed out significance of the rootstock (Amiri et al., 2014). Significant rootstock effect on fruit mineral composition has been indicated in several studies (Joubert et al., 2011; Fazio et al., 2013). Results are sometimes contradictory and depend on rootstocks tested. Most of the studies were performed with well-known rootstocks such as M.9, M.26 and MM.106, some of the studies included seedling rootstocks as well. Modern apple growing is based on rootstocks which are of the same or lower vigour as dwarf M.9, therefore semi-dwarf M.26, semi-vigorous MM.106 and especially vigorous seedling rootstocks are

Please use the following format when citing the article:

Kviklys D., Lanauskas J., Uselis N., Viškelis J.,Viškelienė A., Buskienė L., Staugaitis G., Mažeika R., Samuolienė G. 2017. Rootstock vigour and leaf colour affect apple tree nutrition. Zemdirbyste-Agriculture, 104 (2): 185-190 DOI 10.13080/z-a.2017.104.024 
not used any longer in commercial orchards. Therefore, there is a need to test rootstocks potentially suited for intensive apple growing. This study included mainly new dwarf or super-dwarf rootstocks from Polish rootstock breeding program, and other promising rootstocks selected in East European countries. The aim of the study was to evaluate rootstock impact on apple tree nutrition and fruit mineral content.

\section{Materials and methods}

Planting material. The trial was conducted in a productive orchard (planted in spring 2005) of the Institute of Horticulture, Lithuanian Research Centre for Agriculture and Forestry $\left(55^{\circ} 60^{\prime} \mathrm{N}, 23^{\circ} 48^{\prime} \mathrm{E}\right)$, in 2013-2015. Rootstocks for this trial were chosen based on their popularity worldwide (M.9, M.26, partly B.396 and P22) and suitability for intensive apple (Malus $\times$ domestica Borkh.) growing. Apple rootstocks included in this trial have been tested for their effect on tree growth, productivity and bearing stability (Kviklys et al., 2013; 2016 b) and fruit quality, particularly on fruit phenol content (Kviklys et al., 2014). According to induced tree vigour, the tested rootstocks fall within the following groups: super-dwarf P22, P59, P61 and PB.4, dwarf M.9, P62, P66, P67, B.396 and Pure 1, semi-dwarf M.26. The group of red-leaved rootstocks included B.396, Pure 1 and P59. All other rootstocks were green-leaved. Rootstocks were tested with cvs. 'Ligol' and 'Auksis', both commercially important for East-North Europe. Trees were planted in a randomized block design, with four replicates and three trees per plot.

Soil conditions and orchard management. Trees were planted at planting distance $4 \times 1.5 \mathrm{~m}$ and trained as slender spindles. Weeds in rows were controlled by glyphosate herbicides. Frequently mown grass was kept in alleyways. Pest and disease management was carried out according to the rules of integrated plant protection. $\mathrm{N}$ fertilizers in the rate of $80 \mathrm{~kg} \mathrm{ha}^{-1}$ ( $40 \mathrm{~kg}$ before flowering and $40 \mathrm{~kg}$ two weeks after flowering) and $80 \mathrm{~kg} \mathrm{ha}^{-1}$ of $\mathrm{K}$ fertilizers after harvest were applied annually. The soil in the orchard is Epicalcari-Endohypogleyic Cambisol $(C M g-n-w-c a p)$ : heavy clay loam containing $2.8 \%$ of humus, $255 \mathrm{mg} \mathrm{kg}^{-1} \mathrm{P}_{2} \mathrm{O}_{5}, 230 \mathrm{mg} \mathrm{kg}^{-1} \mathrm{~K}_{2} \mathrm{O}, 7077 \mathrm{mg} \mathrm{kg}^{-1}$ $\mathrm{Ca}$ and $1873 \mathrm{mg} \mathrm{kg}^{-1} \mathrm{Mg}$, with $\mathrm{pH} 7.2$ (in $1 \mathrm{~mol} \mathrm{~L}^{-1} \mathrm{KCl}$ extract) The soil was analysed before establishment of the trial. For leaf, chemical analysis random samples of 50 leaves were taken from middle part of current growth shoots in the middle of July from each replication. Twenty randomly selected fruits from each replication were taken for fruit mineral analysis at harvesting. Leaves and sliced fruits were oven dried to a constant weight.

Agrochemical analysis. Leaf and fruit macronutrient (nitrogen $(\mathrm{N})$, phosphorus $(\mathrm{P})$, potassium $(\mathrm{K})$, calcium $(\mathrm{Ca})$ and magnesium $(\mathrm{Mg}))$ content $(\%$ dry weight $(\mathrm{DW})$ ) and leaf micronutrient (copper $(\mathrm{Cu})$, zinc $(\mathrm{Zn})$, iron $(\mathrm{Fe})$, manganese $(\mathrm{Mn})$ and boron $(\mathrm{B}))$ content $\left(\mathrm{mg} \mathrm{kg}{ }^{-1} \mathrm{DW}\right)$ was measured. The content of leaf and fruit nitrogen was measured by the Kjeldahl method using Tecator Digestion System DK 20 and semiautomatic distillation Unit UDK139 (VelP Scientifica, Italy). Potassium content ( $\% \mathrm{DW})$ was determined by flame photometry with Jenway PFP7 (Bibby Scientific Limited, UK), and the contents of calcium and magnesium by atomic absorption spectrophotometry
AAnalyst 200 (Perkin Elmer, USA). Leaf mineral content for copper $(\mathrm{Cu})$, zinc $(\mathrm{Zn})$, iron $(\mathrm{Fe})$, manganese $(\mathrm{Mn})$ and boron (B) after digestion was extracted with aqua regia and determined with an inductively coupled plasma spectrometer ICP Optima 2100 (Perkin Elmer, USA).

Data analysis. Year to year variation in leaf mineral content was noticed in our trial and, possibly, it was connected with cropping level and weather conditions during particular growing season. On the base of multifactorial analysis, rootstock and year or rootstock and cultivar interactions were significant only in very few cases: therefore results are presented as average of two cultivars and three years.

Deviation of micro- and macronutrients from optimal parameters in apple leaves was evaluated in $\%$, according to formula $\mathrm{N}_{\text {fact }} \times 100 / \mathrm{N}_{\text {opt }}-100$, where $\mathrm{N}_{\text {fact }}$ is particular nutrient content in the sample and $\mathrm{N}_{\text {opt }}$ particular nutrient content considered as optimum (lowest or highest value of optimal range). The $\mathrm{N}_{\text {opt }}$ values were taken from the recommendations for intensive apple orchard growing technology under Lithuanian climate conditions.

For data interpretation all tested rootstocks were separated into three size groups according to trunk cross sectional area: 75-100\% - M.26, M.9, P67, P62 and B.396, 50-75\% - P22, P66, P61 and Pure 1, <50\% - P59 and PB.4, where the most vigorous trees on M.26 are equated to $100 \%$.

The data on the main traits were subjected to the analysis of variance (ANOVA). Significance of differences between rootstock means was estimated by Duncan's multiple-range test at $P<0.05$.

\section{Results}

Leaf mineral content. Average data of two apple cultivars during three years of investigations revealed significant differences between rootstocks in nutrient uptake and accumulation in scion leaves. Rootstocks B.396 and M.26 distinguished themselves among the tested rootstocks by the highest content of almost all minerals detected (Table 1). Rootstock B.396 had lower content of K only, while M.26 accumulated less leaf Ca, $\mathrm{Cu}$ and $\mathrm{Zn}$. Most of $\mathrm{P}$ series rootstocks were low in $\mathrm{N}$ and $\mathrm{Fe}$, but P59 has the highest $\mathrm{Ca}$ and Mn content, and P67 has the highest leaf $\mathrm{Mg}$ and $\mathrm{Cu}$. Rootstock M.9 was between top rootstocks in leaf $\mathrm{N}, \mathrm{P}, \mathrm{K}, \mathrm{Fe}$ and $\mathrm{Cu}$, but has the low of $\mathrm{Mg}$ and $\mathrm{Mn}$. Leaf $\mathrm{K}$ and $\mathrm{Mg}$ were the most dependent on rootstock and the highest number of significant differences between rootstocks were established.

None of the nutrients exceeded limits of optimal content in apple leaves (Table 2). On the other hand, deficient content was recorded only for N, P, K and B. Regardless of rootstock content of all other leaf minerals fall in the optimal range. The highest deficit deviation from optimal content reached $15 \%$ for B and $12 \%$ for $\mathrm{K}$ on average of all rootstocks. The highest total deficit of all nutrients was recorded in leaves from trees on rootstock P59. Total deficit deviation of nutrient content in apple leaves on rootstocks P66, Pure 1, P62 and P61 together with P59 was in the same 40-60\% range, while on rootstocks M.26 and M.9 was lower than $20 \%$.

Red-leaved and green-leaved rootstocks did not significantly differ in most of leaf minerals (Table 3 ). 
Table 1. Rootstock effect on apple leaf mineral content (two cultivars, average 2013-2015)

\begin{tabular}{ccccccccccc}
\hline \multirow{2}{*}{ Rootstock } & $\mathrm{N}$ & $\mathrm{P}$ & $\mathrm{K}$ & $\mathrm{Ca}$ & $\mathrm{Mg}$ & $\mathrm{Fe}$ & $\mathrm{Cu}$ & $\mathrm{Mn}$ & $\mathrm{Zn}$ & $\mathrm{B}$ \\
\cline { 2 - 11 } & \multicolumn{7}{c}{ \% DW } & & \multicolumn{5}{c}{$\mathrm{mg} \mathrm{kg}^{-1} \mathrm{DW}$} \\
\hline B.396 & $2.10 \mathrm{a}$ & $0.161 \mathrm{a}$ & $0.94 \mathrm{de}$ & $1.46 \mathrm{a}$ & $0.29 \mathrm{a}$ & $67.6 \mathrm{ab}$ & $6.74 \mathrm{ab}$ & $83.7 \mathrm{a}$ & $20.6 \mathrm{ab}$ & $21.9 \mathrm{ab}$ \\
M.26 & $2.02 \mathrm{bc}$ & $0.155 \mathrm{ab}$ & $1.06 \mathrm{ab}$ & $1.16 \mathrm{c}$ & $0.28 \mathrm{ab}$ & $70.1 \mathrm{a}$ & $6.03 \mathrm{c}$ & $80.9 \mathrm{ab}$ & $19.5 \mathrm{c}$ & $23.0 \mathrm{ab}$ \\
M.9 & $2.06 \mathrm{ab}$ & $0.156 \mathrm{ab}$ & $1.09 \mathrm{a}$ & $1.24 \mathrm{bc}$ & $0.25 \mathrm{~d}$ & $69.0 \mathrm{a}$ & $6.70 \mathrm{ab}$ & $77.1 \mathrm{ab}$ & $20.8 \mathrm{ab}$ & $21.1 \mathrm{abc}$ \\
P22 & $2.01 \mathrm{bc}$ & $0.151 \mathrm{~b}$ & $1.01 \mathrm{bc}$ & $1.22 \mathrm{bc}$ & $0.25 \mathrm{~d}$ & $63.9 \mathrm{bc}$ & $6.58 \mathrm{ab}$ & $78.1 \mathrm{ab}$ & $21.1 \mathrm{ab}$ & $19.8 \mathrm{bc}$ \\
P59 & $1.93 \mathrm{~d}$ & $0.143 \mathrm{c}$ & $0.89 \mathrm{e}$ & $1.46 \mathrm{a}$ & $0.25 \mathrm{~d}$ & $62.1 \mathrm{bc}$ & $6.87 \mathrm{ab}$ & $83.8 \mathrm{a}$ & $20.7 \mathrm{ab}$ & $18.7 \mathrm{c}$ \\
P61 & $1.92 \mathrm{~d}$ & $0.137 \mathrm{c}$ & $0.91 \mathrm{de}$ & $1.27 \mathrm{~b}$ & $0.27 \mathrm{bc}$ & $58.8 \mathrm{~cd}$ & $6.83 \mathrm{ab}$ & $81.4 \mathrm{a}$ & $20.0 \mathrm{bc}$ & $22.8 \mathrm{ab}$ \\
P62 & $1.96 \mathrm{~cd}$ & $0.140 \mathrm{c}$ & $1.02 \mathrm{bc}$ & $1.22 \mathrm{bc}$ & $0.27 \mathrm{bc}$ & $57.5 \mathrm{~d}$ & $6.35 \mathrm{bc}$ & $79.5 \mathrm{ab}$ & $19.7 \mathrm{bc}$ & $19.0 \mathrm{bc}$ \\
P66 & $1.97 \mathrm{~cd}$ & $0.136 \mathrm{c}$ & $0.88 \mathrm{e}$ & $1.20 \mathrm{bc}$ & $0.29 \mathrm{a}$ & $63.4 \mathrm{bc}$ & $6.53 \mathrm{bc}$ & $80.9 \mathrm{ab}$ & $21.8 \mathrm{a}$ & $20.3 \mathrm{bc}$ \\
P67 & $1.98 \mathrm{c}$ & $0.151 \mathrm{~b}$ & $1.01 \mathrm{bc}$ & $1.21 \mathrm{bc}$ & $0.29 \mathrm{a}$ & $60.8 \mathrm{bcd}$ & $7.18 \mathrm{a}$ & $71.6 \mathrm{~b}$ & $19.2 \mathrm{c}$ & $22.9 \mathrm{ab}$ \\
PB.4 & $1.98 \mathrm{c}$ & $0.134 \mathrm{c}$ & $0.97 \mathrm{~cd}$ & $1.25 \mathrm{bc}$ & $0.21 \mathrm{e}$ & $63.8 \mathrm{bc}$ & $6.90 \mathrm{ab}$ & $78.0 \mathrm{ab}$ & $20.6 \mathrm{ab}$ & $23.3 \mathrm{a}$ \\
Pure 1 & $1.99 \mathrm{c}$ & $0.151 \mathrm{~b}$ & $0.87 \mathrm{e}$ & $1.45 \mathrm{a}$ & $0.26 \mathrm{~cd}$ & $65.6 \mathrm{ab}$ & $7.03 \mathrm{ab}$ & $77.9 \mathrm{ab}$ & $20.7 \mathrm{ab}$ & $20.0 \mathrm{bc}$ \\
\hline
\end{tabular}

Note. DW - dry weight; values with different letters in the columns are significantly different according to Duncan's test at $P<0.05$.

Table 2. Total deviation of micro- and macronutrients from optimal parameters in apple leaves (\%) (two cultivars, average 2013-2015)

\begin{tabular}{cccccccccccc}
\hline & $\mathrm{N}$ & $\mathrm{P}$ & $\mathrm{K}$ & $\mathrm{Ca}$ & $\mathrm{Mg}$ & $\mathrm{Fe}$ & $\mathrm{Cu}$ & $\mathrm{Mn}$ & $\mathrm{Zn}$ & $\mathrm{B}$ & $\mathrm{Sum}$ \\
\hline B.396 & 0 & 0 & -15 & 0 & 0 & 0 & 0 & 0 & 0 & -12 & -27 \\
M.26 & -4 & 0 & -4 & 0 & 0 & 0 & 0 & 0 & 0 & -8 & -16 \\
M.9 & -2 & 0 & -1 & 0 & 0 & 0 & 0 & 0 & 0 & -16 & -19 \\
P22 & -4 & 0 & -8 & 0 & 0 & 0 & 0 & 0 & 0 & -21 & -33 \\
P59 & -8 & -5 & -19 & 0 & 0 & 0 & 0 & 0 & 0 & -5 & -57 \\
P61 & -8 & -9 & -18 & 0 & 0 & 0 & 0 & 0 & 0 & -9 & -45 \\
P62 & -7 & -7 & -7 & 0 & 0 & 0 & 0 & 0 & 0 & -24 & -45 \\
P66 & -6 & -9 & -20 & 0 & 0 & 0 & 0 & 0 & 0 & -19 & -54 \\
P67 & -6 & 0 & -8 & 0 & 0 & 0 & 0 & 0 & 0 & -8 & -22 \\
PB.4 & -6 & -10 & -12 & 0 & -4 & 0 & 0 & 0 & 0 & -7 & -39 \\
Pure 1 & -5 & 0 & -21 & 0 & 0 & 0 & 0 & 0 & 0 & -20 & -46 \\
\hline Average & -5.2 & -3.6 & -12.1 & & -0.38 & & & & & -15.3 & \\
\hline
\end{tabular}

" 0 " - no deviation from optimal range for particular mineral, "-" - deficit amount from the lowest value of optimal range

Table 3. Apple leaf mineral content according to rootstock leaf colour and rootstock induced tree vigour (two cultivars, average 2013-2015)

\begin{tabular}{|c|c|c|c|c|c|c|c|c|c|c|}
\hline \multirow{2}{*}{ Rootstock } & $\mathrm{N}$ & $\mathrm{P}$ & $\mathrm{K}$ & $\mathrm{Ca}$ & $\mathrm{Mg}$ & $\mathrm{Fe}$ & $\mathrm{Cu}$ & $\mathrm{Mn}$ & $\mathrm{Zn}$ & $\mathrm{B}$ \\
\hline & \multicolumn{5}{|c|}{$\% \mathrm{DW}$} & \multicolumn{5}{|c|}{$\mathrm{mg} \mathrm{kg}^{-1} \mathrm{DW}$} \\
\hline Red-leaved rootstocks & $2.01 \mathrm{a}$ & $0.15 \mathrm{a}$ & $0.90 \mathrm{a}$ & $1.45 \mathrm{a}$ & $0.27 \mathrm{a}$ & $65.1 \mathrm{a}$ & $6.88 \mathrm{a}$ & $81.8 \mathrm{a}$ & $20.7 \mathrm{a}$ & $20.2 \mathrm{a}$ \\
\hline Green-leaved rootstocks & $1.99 \mathrm{a}$ & $0.14 \mathrm{a}$ & $1.00 \mathrm{a}$ & $1.22 \mathrm{~b}$ & $0.26 \mathrm{a}$ & $63.4 \mathrm{a}$ & $6.64 \mathrm{a}$ & $78.4 \mathrm{a}$ & $20.3 \mathrm{a}$ & $21.5 \mathrm{a}$ \\
\hline \multicolumn{11}{|l|}{ Rootstock vigour* } \\
\hline$<50 \%$ & $1.95 \mathrm{a}$ & $0.14 \mathrm{a}$ & $0.93 \mathrm{a}$ & $1.35 \mathrm{a}$ & $0.23 \mathrm{~b}$ & $62.9 \mathrm{a}$ & $6.88 \mathrm{a}$ & $80.9 \mathrm{a}$ & $20.6 \mathrm{a}$ & $21.0 \mathrm{a}$ \\
\hline $50-75 \%$ & $1.97 \mathrm{a}$ & $0.14 \mathrm{a}$ & $0.92 \mathrm{a}$ & $1.28 \mathrm{ab}$ & $0.27 \mathrm{ab}$ & $62.9 \mathrm{a}$ & $6.74 \mathrm{a}$ & $79.6 \mathrm{a}$ & $20.9 \mathrm{a}$ & $20.7 \mathrm{a}$ \\
\hline $75-100 \%$ & $2.02 \mathrm{a}$ & $0.15 \mathrm{a}$ & $1.02 \mathrm{a}$ & $1.26 \mathrm{~b}$ & $0.28 \mathrm{a}$ & $65.0 \mathrm{a}$ & $6.60 \mathrm{a}$ & $78.5 \mathrm{a}$ & $20.0 \mathrm{a}$ & $21.6 \mathrm{a}$ \\
\hline
\end{tabular}

Note. ${ }^{*}$ - vigour of trees on M.26 is equal $100 \%$; DW - dry weight; values with different letters in the columns are significantly different according to Duncan's test at $P<0.05$ for rootstock leaf colour and vigour separately.

Only in the case of Ca significantly higher content was detected in red-leaved rootstocks. Significant differences between rootstock vigour groups were established again in $\mathrm{Ca}$ and additionally in $\mathrm{Mg}$ content. The most dwarfing rootstocks accumulated significantly more $\mathrm{Ca}$ and significantly less $\mathrm{Mg}$ in scion leaves than the group of the most vigorous rootstocks. Content of other macro- and micronutrients did not depend on rootstock vigour.

Fruit mineral content. Significant effect of rootstock on fruit mineral content was found for all investigated minerals (Table 4). Fruit $\mathrm{Mg}$ was least variable: $18 \%$ difference was established between rootstock M.26 with the highest $\mathrm{Mg}$ content and rootstocks Pure 1 and P59 with the lowest fruit Mg. The highest difference was found in fruit P content $-28 \%$ between high rootstocks P67 and P62 and low rootstock PB.4. Rootstocks P67 and M.26 were among top three rootstocks in accumulation of all fruit minerals with the exception of $\mathrm{Ca}$. The highest content of $\mathrm{Ca}$ was in fruits from trees on rootstocks P59, Pure 1 and P66, though accumulation of other fruit minerals in trees on these rootstocks was low in almost all cases.

$\mathrm{K}, \mathrm{Mg}$ and $\mathrm{N}$ ratios to $\mathrm{Ca}$ in apple fruits is important for fruit storage and bitter pit incidence. The highest $\mathrm{K}, \mathrm{N}$ and $\mathrm{Mg}$ ratios to $\mathrm{Ca}$ were found in fruits from trees grown on rootstocks P67 and M.26, and partially on M.9 and P62 (Table 5). The lowest ratio was in fruits on rootstocks P59, P66 and Pure 1. 
Table 4. Rootstock effect on apple fruit mineral content (\% DW) (two cultivars, average 2013-2015)

\begin{tabular}{cccccc}
\hline Rootstock & $\mathrm{N}$ & $\mathrm{P}$ & $\mathrm{K}$ & $\mathrm{Ca}$ & $\mathrm{Mg}$ \\
\hline B.396 & $0.253 \mathrm{~b}$ & $0.069 \mathrm{ab}$ & $0.419 \mathrm{~b}$ & $0.023 \mathrm{bc}$ & $0.030 \mathrm{ab}$ \\
M.26 & $0.256 \mathrm{ab}$ & $0.070 \mathrm{ab}$ & $0.513 \mathrm{a}$ & $0.021 \mathrm{c}$ & $0.033 \mathrm{a}$ \\
M.9 & $0.255 \mathrm{ab}$ & $0.065 \mathrm{bc}$ & $0.493 \mathrm{a}$ & $0.022 \mathrm{c}$ & $0.032 \mathrm{a}$ \\
P22 & $0.219 \mathrm{c}$ & $0.062 \mathrm{~cd}$ & $0.427 \mathrm{~b}$ & $0.022 \mathrm{c}$ & $0.030 \mathrm{ab}$ \\
P59 & $0.241 \mathrm{bc}$ & $0.060 \mathrm{~cd}$ & $0.407 \mathrm{~b}$ & $0.028 \mathrm{a}$ & $0.027 \mathrm{~b}$ \\
P61 & $0.214 \mathrm{c}$ & $0.064 \mathrm{bc}$ & $0.419 \mathrm{~b}$ & $0.024 \mathrm{bc}$ & $0.029 \mathrm{~b}$ \\
P62 & $0.242 \mathrm{~b}$ & $0.072 \mathrm{a}$ & $0.507 \mathrm{a}$ & $0.021 \mathrm{c}$ & $0.031 \mathrm{ab}$ \\
P66 & $0.229 \mathrm{c}$ & $0.062 \mathrm{~cd}$ & $0.396 \mathrm{~b}$ & $0.026 \mathrm{ab}$ & $0.029 \mathrm{~b}$ \\
P67 & $0.275 \mathrm{a}$ & $0.072 \mathrm{a}$ & $0.508 \mathrm{a}$ & $0.021 \mathrm{c}$ & $0.031 \mathrm{ab}$ \\
PB.4 & $0.246 \mathrm{~b}$ & $0.052 \mathrm{e}$ & $0.419 \mathrm{~b}$ & $0.022 \mathrm{c}$ & $0.028 \mathrm{~b}$ \\
Pure 1 & $0.218 \mathrm{c}$ & $0.057 \mathrm{de}$ & $0.413 \mathrm{~b}$ & $0.026 \mathrm{ab}$ & $0.027 \mathrm{~b}$ \\
\hline
\end{tabular}

Note. DW - dry weight; values with different letters in the columns are significantly different according to Duncan's test at $P<0.05$.

Table 5. Rootstock effect on the ratio of minerals in apple fruits (two cultivars, average 2013-2015)

\begin{tabular}{ccccc}
\hline Rootstock & $\mathrm{N}: \mathrm{Ca}$ & $\mathrm{K}: \mathrm{Ca}$ & $\mathrm{Mg}: \mathrm{Ca}$ & $(\mathrm{N}+\mathrm{K}): \mathrm{Ca}$ \\
\hline B.396 & $11.1 \mathrm{bc}$ & $19 \mathrm{bc}$ & $1.33 \mathrm{bc}$ & $30 \mathrm{bc}$ \\
M.26 & $11.9 \mathrm{ab}$ & $24 \mathrm{a}$ & $1.53 \mathrm{a}$ & $36 \mathrm{a}$ \\
M.9 & $11.5 \mathrm{~b}$ & $22 \mathrm{ab}$ & $1.43 \mathrm{ab}$ & $34 \mathrm{ab}$ \\
P 22 & $10.1 \mathrm{~cd}$ & $20 \mathrm{bc}$ & $1.43 \mathrm{ab}$ & $30 \mathrm{bc}$ \\
P 59 & $8.7 \mathrm{~d}$ & $15 \mathrm{e}$ & $0.98 \mathrm{e}$ & $23 \mathrm{~d}$ \\
P 61 & $8.9 \mathrm{~d}$ & $18 \mathrm{ce}$ & $1.21 \mathrm{~cd}$ & $26 \mathrm{~cd}$ \\
P 62 & $11.4 \mathrm{bc}$ & $25 \mathrm{a}$ & $1.48 \mathrm{ab}$ & $36 \mathrm{a}$ \\
P 66 & $8.8 \mathrm{~d}$ & $15 \mathrm{e}$ & $1.12 \mathrm{de}$ & $24 \mathrm{~d}$ \\
P 67 & $13.4 \mathrm{a}$ & $25 \mathrm{a}$ & $1.55 \mathrm{a}$ & $38 \mathrm{a}$ \\
PB.4 & $11.3 \mathrm{bc}$ & $19 \mathrm{bc}$ & $1.30 \mathrm{bc}$ & $30 \mathrm{bc}$ \\
Pure 1 & $8.4 \mathrm{~d}$ & $16 \mathrm{ce}$ & $1.06 \mathrm{de}$ & $24 \mathrm{~d}$ \\
\hline
\end{tabular}

Note. Values with different letters in the columns are significantly different according to Duncan's test at $P<0.05$.

Significant differences between red-leaved and green-leaved rootstocks were found investigating accumulation of $\mathrm{Ca}$ and $\mathrm{K}$ in apple fruits (Table 6). Content of fruit $\mathrm{Ca}$ was significantly higher from trees on red-leaved rootstocks, but content of fruit $\mathrm{K}$ was significantly lower than from trees on green-leaved rootstocks. $\mathrm{N}, \mathrm{K}$ and $\mathrm{Mg}$ ratios to $\mathrm{Ca}$ were always lower on red-leaved rootstocks.

Table 6. Apple fruit mineral content and their ratios according to rootstock leaf colour and rootstock induced tree vigour (\% DW) (average 2013-2015)

\begin{tabular}{cccccccccc}
\hline Rootstock & $\mathrm{N}$ & $\mathrm{P}$ & $\mathrm{K}$ & $\mathrm{Ca}$ & $\mathrm{Mg}$ & $\mathrm{K}: \mathrm{Ca}$ & $\mathrm{N}: \mathrm{Ca}$ & $\mathrm{Mg}: \mathrm{Ca}$ & $(\mathrm{N}+\mathrm{K}): \mathrm{Ca}$ \\
\hline Red-leaved rootstocks & $0.24 \mathrm{a}$ & $0.06 \mathrm{a}$ & $0.41 \mathrm{~b}$ & $0.026 \mathrm{a}$ & $0.028 \mathrm{a}$ & $16.2 \mathrm{~b}$ & $9.3 \mathrm{~b}$ & $1.1 \mathrm{~b}$ & $25.5 \mathrm{~b}$ \\
Green-leaved rootstocks & $0.24 \mathrm{a}$ & $0.06 \mathrm{a}$ & $0.46 \mathrm{a}$ & $0.022 \mathrm{~b}$ & $0.030 \mathrm{a}$ & $20.5 \mathrm{a}$ & $11.0 \mathrm{a}$ & $1.4 \mathrm{a}$ & $31.3 \mathrm{a}$ \\
\hline Rootstock vigour* & & & & & & & & & \\
$<50$ & $0.243 \mathrm{a}$ & $0.056 \mathrm{~b}$ & $0.413 \mathrm{~b}$ & $0.025 \mathrm{a}$ & $0.028 \mathrm{a}$ & $17 \mathrm{~b}$ & $10 \mathrm{~b}$ & $1.1 \mathrm{~b}$ & $26 \mathrm{~b}$ \\
$50-75$ & $0.220 \mathrm{a}$ & $0.061 \mathrm{ab}$ & $0.414 \mathrm{~b}$ & $0.025 \mathrm{a}$ & $0.029 \mathrm{a}$ & $17 \mathrm{~b}$ & $9 \mathrm{~b}$ & $1.2 \mathrm{~b}$ & $26 \mathrm{~b}$ \\
$75-100$ & $0.256 \mathrm{a}$ & $0.070 \mathrm{a}$ & $0.488 \mathrm{a}$ & $0.022 \mathrm{a}$ & $0.031 \mathrm{a}$ & $23 \mathrm{a}$ & $12 \mathrm{a}$ & $1.4 \mathrm{a}$ & $34 \mathrm{a}$ \\
\hline
\end{tabular}

Note. ${ }^{*}$ - vigour of trees on M.26 is equal $100 \%$; DW - dry weight; values with different letters in the columns are significantly different according to Duncan's test at $P<0.05$ for rootstock leaf colour and vigour separately.

Accumulation of $\mathrm{P}$ and $\mathrm{K}$ in fruits also depended on rootstock induced tree vigour (Table 6). The group of most vigorous rootstocks determined significantly higher content of these minerals and showed tendency to accumulate more $\mathrm{N}$ and $\mathrm{Mg}$ as well. $\mathrm{K}, \mathrm{N}$ and $\mathrm{Mg}$ ratios to $\mathrm{Ca}$ were significantly higher in the group of most vigorous rootstocks.

\section{Discussion}

All elements of growing technology should be fulfilled precisely in modern high density apple orchards. Optimal tree nutrition is one of the main prerequisites for high yields, good quality fruits and desired vegetative tree growth. Rootstocks are selective in nutrient uptake, and it became important when regulating orchard nutrition strategy and decreasing leaching of fertilizers. Significant differences between apple trees on various rootstocks in leaf and fruit mineral content were obtained in our trial.

Results of trial performed in Poland showed that it is difficult to relate significant differences between rootstocks to their vigour (Slowinski, Sadowski, 2001). At the same time, other researches indicate higher content of nutrients on more vigorous rootstocks: MM.106 prevailed M.9 and M.26 (Kucukyumuk, Erdal, 2011), seedling rootstocks prevailed dwarfing rootstocks in accumulation of some minerals (Amiri et al., 2014). That was partly confirmed by our results. The most 
vigorous rootstocks in the trial M.26, M.9, B.396 and P67 accumulated more leaf minerals and had lower deficit deviation from optimal content. The highest total deficit of leaf minerals was detected on super-dwarfing rootstock P59. On the other hand, when all rootstocks were grouped according to induced tree vigour, leaf mineral content except $\mathrm{Ca}$ and $\mathrm{Mg}$ did not differ. Significant differences of the content of above mentioned nutrients were found only between contrasting the most and the least vigorous rootstock groups, where smaller rootstocks accumulated more $\mathrm{Ca}$, whereas more vigorous rootstocks accumulated significantly more $\mathrm{Mg}$. Fallahi et al. (2002) have reported that $\mathrm{Mg}$ content was always greater in trees on M.26. Correlation between vigour of rootstock and calcium content in leaves was also found in trials performed in Poland (Kruczynska et al., 1990), where leaf calcium content was significantly higher in trees on dwarf B.9, P16 and M.9. Fallahi and Mohan (2000) showed that dwarf M.9 had higher leaf Ca than semi-vigorous rootstocks MM.106 and MM.111.

Possibly, the group of our tested rootstocks was not so contrasting in tree growth control (the range was from super-dwarf to semi-dwarf rootstocks) and differences in accumulation of other minerals in scion leaves were not so evident or it indicates that rootstock genotype but not its vigour determines leaf mineral content of scion cultivars.

Rootstock B.9 is incorporated into the progeny of all red-leaved rootstocks included in our trial. Besides some other features, several researchers indicated better $\mathrm{Ca}$ uptake in trees grafted on red-leaved rootstocks (Fallahi et al., 2001; Pietranek, Jadczuk, 2005). Our data confirmed these findings. Content of $\mathrm{Ca}$ in leaves of trees on red-leaved rootstocks was significantly higher than on green-leaved rootstocks. At the same time, content of other nutrients did not differ between both rootstock types.

Fruit mineral content sometimes is correlated with fruit quality parameters. Jivan and Sala (2014) found that $\mathrm{N}$ correlated with fruit acidity and $\mathrm{Zn}$ with sugars. Mineral content is usually more related to fruit storability, which is in large extent attributed to $\mathrm{Ca}$ content in fruits or to $\mathrm{Ca}$ ratio to other fruit minerals. Low accumulation of $\mathrm{Ca}$ in fruits may lead to low quality fruits and storage disorders as bitter pit or superficial scald. Application of liquid $\mathrm{Ca}$ fertilizers is a common practice in apple growing technology, however with different degree of success (Rosenberger et al., 2004; Lanauskas et al., 2012). Obvious rootstock effect on $\mathrm{Ca}$ accumulation in fruits can lead to creation of new rootstock and cultivar combinations, especially for apple cultivars that are prone to $\mathrm{Ca}$ related disorders.

Red-leaved rootstocks had a positive effect not only on accumulation of $\mathrm{Ca}$ in leaves but in fruits of scion cultivars as well. Higher content of fruit $\mathrm{Ca}$ on red-leaved rootstocks was demonstrated in other trials too (Słowińska, Tomala, 2001; Maas, Wertheim, 2004; Skrzyński, 2007). Along with high calcium content low $\mathrm{K}: \mathrm{Ca}, \mathrm{Mg}: \mathrm{Ca}$ and $\mathrm{N}$ :Ca ratios are a prerequisite for good fruit storability (Sio et al., 1999; Piestrzeniewicz, Tomala, 2001; Casero et al., 2009). Red-leaved rootstocks tested in our trial in all cases demonstrated more desirable ratios.

Słowińska and Tomala (2001) did not find relationship between rootstock effect on fruit $\mathrm{Mg}, \mathrm{P}$ and $\mathrm{K}$ and rootstock vigour. In our study, apple trees on most vigorous rootstocks accumulated significantly higher amount of $\mathrm{K}$ and $\mathrm{P}$. Benefits of more dwarfing rootstocks were most evident in Ca ratio with other minerals, stating possibility of these apples for better storage and lesser susceptibility to storage disorders.

\section{Conclusions}

1. Apple cultivars 'Auksis' and 'Ligol' on semidwarf M.26 and dwarf P67 rootstocks accumulated more leaf and fruit minerals than on other tested rootstocks. The highest negative deviation from optimal content was detected in leaves from trees on super-dwarf rootstock P59.

2. Apple cultivars 'Auksis' and 'Ligol' on redleaved rootstocks accumulated significantly more $\mathrm{Ca}$ in leaves and fruits. Significantly lower $\mathrm{K}, \mathrm{N}$ and $\mathrm{Mg}$ ratios to $\mathrm{Ca}$ were detected in apples from trees on red-leaved rootstocks.

3. Rootstock vigour had impact on leaf calcium and magnesium of scion cultivars. More dwarfing rootstocks determined higher content of leaf $\mathrm{Ca}$ and lower content of leaf $\mathrm{Mg}$. More vigorous rootstocks had positive effect on fruit $\mathrm{K}$ and $\mathrm{P}$, while dwarfing on $\mathrm{K}, \mathrm{N}$ and $\mathrm{Mg}$ ratios to $\mathrm{Ca}$.

\section{Acknowledgements}

This research was funded by a grant (No. MIP036/2014) from the Research Council of Lithuania.

Received 29112016

Accepted 02022017

\section{References}

Amiri M., Fallahi E., Safi-Songhorabad M. 2014. Influence of rootstock on mineral uptake and scion growth of 'Golden delicious' and 'Royal Gala' apples. Journal of Plant Nutrition, 37: 16-29 https://doi.org/10.1080/01904167.2013.792838

Auvil T. D., Schmidt T. R., Hanrahan I., Castillo F., McFerson J. R., Fazio G. 2011. Evaluation of dwarfing rootstocks in Washington apple replant sites. Acta Horticulturae (ISHS), 903: 265-271 https://doi.org/10.17660/ActaHortic.2011.903.33

Casero T., Benavides A. L., Recasens I. 2009. Interrelation between fruit mineral content and pre-harvest calcium treatments on 'Golden Smoothee' apple quality. Journal of Plant Nutrition, 33 (1): 27-37

https://doi.org/10.1080/01904160903391057

Fallahi E., Mohan S. K. 2000. Influence of nitrogen and rootstock on tree growth, precocity, fruit quality, leaf mineral nutrients, and fire blight in 'Scarlet Gala' apple. HortTechnology, 10: 589-592

Fallahi E., Chun I., Neilsen G. H., Colt W. M. 2001. Effects of three rootstocks on photosynthesis, leaf mineral nutrition, and vegetative growth of 'BC-2 Fuji' apple trees. Journal of Plant Nutrition. 24 (6): 827-834 https://doi.org/10.1081/PLN-100103776

Fallahi E., Colt W. M., Fallahi B., Chun I.-J. 2002. The importance of apple rootstocks on tree growth, yield, fruit quality, leaf nutrition, and photosynthesis with an emphasis on 'Fuji'. HortTechnology, 12 (6): 38-44

Fazio G., Kviklys D., Grusak M. A., Robinson T. L. 2013. Phenotypic diversity and QTL mapping of absorption and translocation of nutrients by apple rootstocks. Aspects of Applied Biology, 119: 37-50

Jivan C., Sala F. 2014. Relationship between tree nutritional status and apple quality. Horticultural Science (Prague), 41: $1-9$ 
Joubert J., Stassen P. J. C., Wooldridge J. 2011. Effect of rootstock on leaf and fruit macro-element composition in 'Reinders Golden Delicious' apple. Acta Horticulturae (ISHS). 903: 391-396 https://doi.org/10.17660/ActaHortic.2011.903.51

Kruczynska D., Olszewski T., Czynczyk A., Staszak A. 1990. Preliminary results of rootstock and interstem combination effect on growth, yield and leaf mineral content of two apple cultivars 'Delikates' and 'Empire'. Acta Horticulturae (ISHS), 274: 257-266 https://doi.org/10.17660/ActaHortic.1990.274.30

Kucukyumuk Z., Erdal I. 2011. Rootstock and cultivar effect on mineral nutrition, seasonal nutrient variation and correlations among leaf, flower and fruit nutrient concentrations in apple trees. Bulgarian Journal of Agricultural Sciences, 17: 633-641

Kviklys D., Kviklienė N., Bielicki P., Bite A., Lepsis J., Univer T., Univer N., Uselis N., Lanauskas J. 2013. Baltic fruit rootstock studies: evaluation of apple (Malus domestica Borkh.) new rootstocks. ZemdirbysteAgriculture. 100 (4): 441-446 https://doi.org/10.13080/z-a.2013.100.056

Kviklys D., Liaudanskas M., Janulis V., Viškelis P., Rubinskienė M., Lanauskas J., Uselis N. 2014. Rootstock genotype determines phenol content in apple fruits. Plant, Soil and Environment, 60 (5): 234-240

Kviklys D., Robinson T. L., Fazio G. 2016 (a). Apple rootstock evaluation for apple replant disease. Acta Horticulturae (ISHS). 1130: 425-430 https://doi.org/10.17660/ActaHortic.2016.1130.63

Kviklys D., Ceidaitė A., Lanauskas J., Uselis N., Samuolienė G. 2016 (b). The effect of rootstock on apple tree bearing stability in a cooler climate. Agricultural and Food Science, $25(1): 81-88$

Lanauskas J., Kviklienè N., Uselis N., Kviklys D., Buskienė L., Mažeika R., Staugaitis G. 2012. The effect of calcium foliar fertilizers on cv. Ligol apples. Plant, Soil and Environment, 58 (10): 465-470
Maas F. M., Wertheim S. J. 2004. A multi-site rootstock trial with the apple cultivars 'Cox's Orange Pippin' and 'Jonagold'. Acta Horticulturae (ISHS). 658 (1): 177-184

https://doi.org/10.17660/ActaHortic.2004.658.25

Piestrzeniewicz C., Tomala K. 2001. Some factors influencing storage ability of 'Jonagold' apples. Acta Horticulturae (ISHS), 564: 435-442 https://doi.org/10.17660/ActaHortic.2001.564.54

Pietranek A., Jadczuk E. 2005. Mineral status of 'Katja' apple trees depending on irrigation, fertilisation and rootstock. Acta Scientiarum Polonorum, Hortorum Cultus, 4: 69-76

Rosenberger D. A., Schupp J. R., Hoying S. A., Cheng L., Watkins C. B. 2004. Controlling bitter pit in 'Honeycrisp' apples. HortTechnology, 14 (3): 342-349

Samuolienè G., Čeidaitė A., Sirtautas R., Duchovskis P., Kviklys D. 2016. Effect of crop load on phytohormones, sugars, and biennial bearing in apple trees. Biologia Plantarum. 60: 394 https://doi.org/10.1007/s10535-015-0581-3

Sio J., Boixadera J., Rosera J. 1999. Effect of orchard factors and mineral nutrition on bitter pit in 'Golden delicious' apples. Acta Horticulturae (ISHS), 485: 331-334 https://doi.org/10.17660/ActaHortic.1999.485.46

Skrzyński J. 2007. The effect of rootstocks on the retention of apple quality. Acta Horticulturae (ISHS). 732: 155-158 https://doi.org/10.17660/ActaHortic.2007.732.18

Słowińska I., Tomala K. 2011. Rootstock effect on mineral composition and storability of 'Elise' apple. Folia Horticulturae, 13 (2): 69-74

Slowinski A., Sadowski A. 2001. Mineral element content in leaves of different apple rootstocks and of 'Elise' scion cultivar on the same rootstocks. Acta Horticulturae (ISHS), 564: 309-316 https://doi.org/10.17660/ActaHortic.2001.564.36

Wertheim S. J. 1998. Rootstock guide: apple, pear, cherry, European plum. Fruit Research Station, Wilhelminadorp, The Netherlands, $144 \mathrm{p}$.

ISSN 1392-3196 / e-ISSN 2335-8947

Zemdirbyste-Agriculture, vol. 104, No. 2 (2017), p. 185-190

DOI 10.13080/z-a.2017.104.024

\title{
Poskiepio augumo ir lapų spalvos ịtaka obels vaismedžių mitybai
}

\author{
D. Kviklys ${ }^{1}$, J. Lanauskas ${ }^{1}$, N. Uselis ${ }^{1,3}, J_{\text {. Viškelis }}{ }^{1}$, A. Viškelienè $^{1}$, L. Buskienè $\dot{e}^{1}$, \\ G. Staugaitis², R. Mažeika², G. Samuolienè $\dot{e}^{1,3}$
}

${ }^{1}$ Lietuvos agrarinių ir miškų mokslų centro Sodininkystès ir daržininkystès institutas

${ }^{2}$ Lietuvos agrarinių ir miškų mokslų centro Agrocheminių tyrimų laboratorija

${ }^{3}$ Aleksandro Stulginskio universitetas

\section{Santrauka}

2013-2015 m. tirta obelų poskiepių M.9, M.26, B.396, P22, P59, P61, P62, P66, P67, Pure 1 ir PB.4 įtaka veisliu 'Ligol' bei 'Auksis' lapų ir vaisių mineralinei sudèčiai. Nustatyti azoto $(\mathrm{N})$, fosforo $(\mathrm{P})$, kalio $(\mathrm{K})$, kalcio $(\mathrm{Ca})$ bei magnio $(\mathrm{Mg})$ kiekiai obuoliuose bei lapuose ir vario $(\mathrm{Cu})$, geležies $(\mathrm{Fe})$, cinko $(\mathrm{Zn})$, mangano $(\mathrm{Mn})$ bei boro $(\mathrm{B})$ kiekiai lapuose. Daugiausia mineralinès mitybos elementų lapuose ir vaisiuose sukaupè vaismedžiai su pusiau žemaūgiu poskiepiu M.26 ir žemaūgiu poskiepiu P67. Didžiausias neigiamas nuokrypis nuo optimalių mineralinės mitybos elementų kiekių nustatytas vaismedžių su nykštukiniu poskiepiu P59 lapuose. Iš esmès daugiau Ca lapuose ir vaisiuose sukaupė vaismedžiai su raudonlapiais poskiepiais, o elementų $\mathrm{K}: \mathrm{Ca}, \mathrm{N}: \mathrm{Ca}$ ir $\mathrm{Mg}: \mathrm{Ca}$ santykiai buvo mažesni. Poskiepio augumas lėmè $\mathrm{Ca}$ ir $\mathrm{Mg}$ kiekị lapuose. Vaismedžių augumą labiausiai ribojantys poskiepiai lèmé iš esmès didesnị $\mathrm{Ca}$ ir mažesnị $\mathrm{Mg}$ kiekị lapuose. Augiausi poskiepiai didino $\mathrm{K}$ ir $\mathrm{P}$ kiekius vaisiuose, o žemaūgiai poskiepiai mažino $\mathrm{K}: \mathrm{Ca}, \mathrm{N}: \mathrm{Ca}$ ir $\mathrm{Mg}$ :Ca santykių reikšmes. Atsižvelgiant ị poskiepio įtaką mineralinių elementų įsisavinimui, galima prognozuoti obelų sodų mineralinę mitybą įvairiuose dirvožemiuose.

Reikšminiai žodžiai: lapas, Malus × domestica, mineralinè sudètis, vaisius. 